\title{
Statyba
}

ISSN: 1392-1525 (Print) (Online) Journal homepage: https://www.tandfonline.com/loi/tcem19

\section{MODEL OF RATIONAL HOUSING IN LITHUANIA}

\section{A. Banaitis}

To cite this article: A. Banaitis (2000) MODEL OF RATIONAL HOUSING IN LITHUANIA, Statyba, 6:6, 451-456, DOI: $10.1080 / 13921525.2000 .10531630$

To link to this article: https://doi.org/10.1080/13921525.2000.10531630

Published online: 26 Jul 2012.

Submit your article to this journal $\pi$

Џll Article views: 88

4 Citing articles: 1 View citing articles 준 


\section{MODEL OF RATIONAL HOUSING IN LITHUANIA}

A. Banaitis

Vilnius Gediminas Technical University.

\section{Introduction}

Development of housing takes an important place in economic, social and technological activities of a state. At the present moment, among the changes of public, economic, social situation in Lithuania, problems of housing are especially urgent. After the decrease in housing construction and investments in the country, the lack of dwellings has been revealed, problems of homeless people become pressing.

Housing problems are manifold and no complex examinations thereof have been made yet. A lot of variable factors of micro- and macro-level determines the efficiency of housing and trends of its development. Variable factors of macro-level such as a level of economic, social and technological situation of a country, documents regulating construction industry, monetary and fiscal system, inflation, situation on the market, etc, and factors of micro-level such as activities of construction industry companies, financing building organizations, qualification improvement of employees, processes of design, construction and maintenance, etc have a complex influence on the efficiency and development of housing.

The general regularities of these factors affecting the efficiency of housing. trends of their development. mutual dependence are not clear enough. In the present dynamic situation. a question arises how impartially to make prognoses of the future volume of housing. One of possibilities is modelling Lithuanian housing in order to examine the eflicient surroundings of housing. ic 10 determine variable factors of micro- and macroletel that could increase the effectual activities of housing.

The current state of housing and the trends of its development were analyzed from various conceptual and quantitative perspectives by a number of scientists. For instance, P. Balchin [1] studied economic, social and political problems related to dwelling acquisition. M. Ball [2] considered the problems of reducing state expenditures on dwelling, crediting, long-term loans and their various economic, social and political aspects. R. C. Harvey [3] discussed the way the government can affect the housing market through finances, regulating documentation and contracts. In particular, he studied the UK dwelling subsidies, funding and taxes and their effect on demand and offer. J. Hegedus [4] investigated housing strategy in Central and Eastern Europe while P. H. Hillebrandt [5] considered the ways of saving energy in operating buildings. J. Hills [6] summarized the cases when the government may intervene into housing market and the instruments of this intervention. $\mathrm{He}$ also dealt with some social problems related to housing. J. Sillince [7] studied some economic, social and political problems of housing. Conceptual and quantitative study of these problems was also performed by $A$. von Hoffman [8], P. Malpass [9], C. Zimmermann [10] and others.

Researchers from various countries use conceptual and quantitative forms of analysis while studying the effect of certain factors on the housing efficiency. However. the papers mentioned did not deal with a complex approach to housing without taking into account economic. quality. social. technological. infrastructural. legislatise and other factors.

The main objective of this research is 10 present an analstical model of complex analysis of rational housing. following the variable factors of micro- and macro-lesel surroundings which determine effective selection of housing. to describe these factors comprehensively taking into consideration the gained experience and knowledge in advanced countries and countries of Central and Eastern Europe (CEE), to apply methods of multiple criteria analysis for solving problems of micro- and macro-level of housing, to prepare comparative 
systems of indices comprehensively describing the housing. Implementation of this purpose allows to reach the complex increase in housing effectiveness.

\section{Main stages of working out a model of rational housing in Lithuania}

This research seeks to explore ways of harmonizing the relationship between the transition Lithuanian housing and its environment. The research includes the stages presented in Fig 1.

A model in the research is being considered as the system of specific rules in presence of which the housing of Lithuania would apply its potential opportunities. Prospects of future Lithuanian housing and the principal trends of development are linked with analysis of experience and knowledge gathered by advanced and CEE countries, and application thereof having evaluated the specific features of Lithuania. Having used expert methods and analysis of scientific literature, the micro- and macro-level factors are being determined as well as the systems and sub-systems of indices describing them, describing housing in the initial stage. In accordance with the made systems of indices, a situation of housing in Lithuania, CEE and advanced countries is being described conceptually and quantitatively. Following the gathered information, a data-base is made describing variable indices of micro- and macrolevel of various countries and their influence on housing. Inviting the information gathered in the database to help, the trends of housing development of advanced, CEE countries, differences of these countries and Lithuania in this field are determined [11].

Having made an analysis of housing differences in Lithuania, CEE and advanced countries on the microand macro-level, the tendencies of development of housing of Lithuania are determined.

In order to throw more light on the subject, further follow more detailed description of the some above mentioned stages of analysis.

\section{Developing housing indicators}

Indicators have been used informally for a very long time, particularly in economics, to evaluate the state of the nation and progress towards national objectives.

\begin{tabular}{|l|l|l|l|l|l|}
\hline $\begin{array}{l}\text { Determination and description of micro- and } \\
\text { macro-level factors affecting the efficiency } \\
\text { of housing. Development of some systems of } \\
\text { indices describing these factors and their } \\
\text { effect on housing }\end{array}$ & $\begin{array}{l}\text { II STAGE } \\
\text { Conceptual analysis of } \\
\text { mutual effect of micro- and } \\
\text { macro-level factors and } \\
\text { their influence on the } \\
\text { housing efficiency }\end{array}$
\end{tabular}

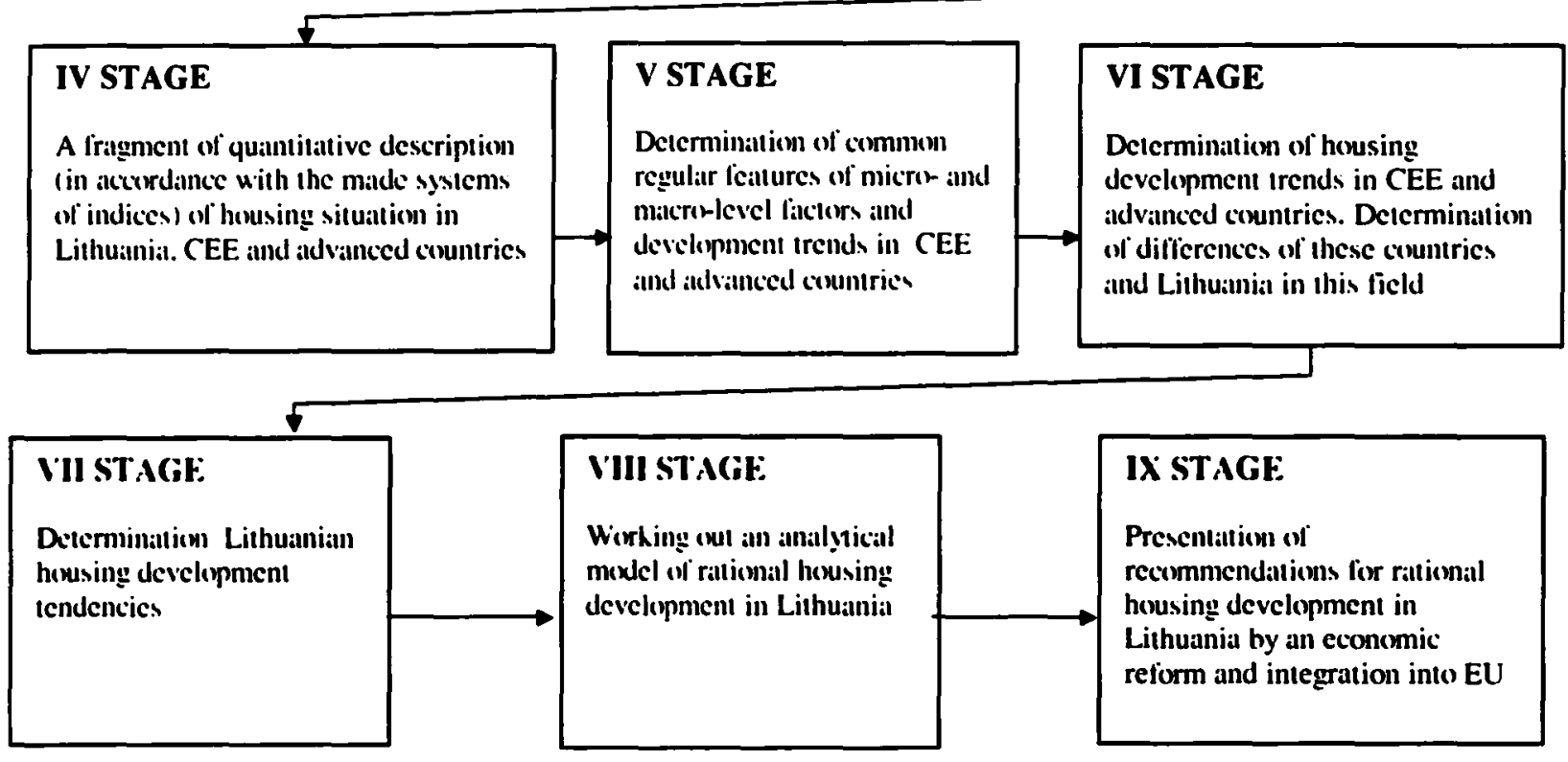

Fig 1. Main stages of working out a model of rational housing 
Basically studies on housing indicators have related to particular parts of housing policy, such as housing needs or housing and neighborhood quality rather than to the housing as a whole [12]. Housing Indicators Program was initiated by World Bank and UN Centre for Human Settlement (Habitat) in 1990 and about 150 indicators have been undertaken in several countries. This model is broadly applicable to all policy areas, including housing. However Lithuanian and CEE housing has some unique features that are likely to require special attention.

The performed examinations [11] showed that while solving the problems of housing it is important to create the complex comparative systems of indices describing the housing. Two following systems of indices are suggested in the research:

- Complex system of indices allowing to evaluate the trends of housing policy and activities on a world-scale and allowing to evaluate the housing in countries of different economic development. System of indices allows to determine the problematic fields of housing and contradicting objectives of politics. The system includes indices divided into five groups: indices describing economics as a whole complex (GDP per capita; registered unemployment rate; inflation; rate of interest); indices describing the housing construction, investments and financing (construction of dwellings per 1000 inhabitants, average useful floor space per dwelling, housing investments as a share of GDP, house price to income ratio, rent to income ratio, housing expenditure, mortgage to credit ratio, long term loans); indices describing the countries of transitional period (price liberalization, competition policy, banking reform and interest rate liberalization, governance and restructuring, securities markets and non-bank financial institutions. extensiveness and effectiveness of legal rules on investment): indices descrihing the volumc', quantity and density of housing (dwellings per 1000 population. average useful floor space per person. average household size. occupants per dwelling. dwellings with piped water. duellings with fixed bath shower. dwellings with llush toilet): indices descrihing the honsing policy (dwellings by type of tenure. repair. renovation and energy efficiency, reduction of public expenditure on housing. policy must adequately reflect real situation in country).

- The complex system of housing indices intended to evaluate housing of Lithuania. A system of such group of indices shows potential problems of Lithuanian housing and assists in finding out methods and means to improve the current situation. The system covers indices divided into six groups: economic (investment in housing, potential capacities of housing, public investment instruments, private investment instruments, rental policy, systems of housing subsidy); social (policies on social housing, social housing affordability and time of waiting); qualitative, volume and densing (construction of new dwellings, dwellings by period of construction. classification of dwellings according to equipment, renovation, energy efficiency, land supply for housing): institutional structures (Seimas / Parliament, central government, counties, local authorities, private sector, owners associations); legal bases (law on local authority, law on housing subsidies, law on housing finance and credits, law on construction and maintenance, law on housing acquisition, law on rental housing, law on owners associations, law on restitution of ownership rights to residential houses, harmonization of the legislation and regulation on construction in conformity with those used in EU; political priorities (Seimas / Parliament level, governmental level, county level, local authority level).

Following the made systems of housing indices, a comparative analysis of Lithuania, 16 countries of Western Europe, $11 \mathrm{CEE}$ countries and the USA is made, housing of Lithuania evaluated. Following the analysis, the fields of Lithuanian housing has been determined where the current situation is corresponding, partly corresponding and not corresponding to the practice of advanced countries and CEE countries [11].

\section{A complex description of housing in conceptual and quantitative languages}

An accuracy degree of quantitative description of the housing largely depends on the availability and accuracy of the data as well as on the form of its quantitative presentation. The role of information accuracy is growing with time. The highest accuracy degree of intormation is reached when it can be expressed in numbers. Therefore. one of the major tasks in creating a model of a rational housing in Lithuania is adequate quantitative presentation of housing activities.

The essence of the process is accurate presentation of system factors in numerical form and indication of their specific measuring units [13]. 
The efficiency of the housing in a country is largely affected by its economic. political and social situation as well as by such factors as technological development, environment protection, etc. Also various interested parties are involved in housing. Therefore. the variety of measuring units must correspond to the variety of criteria reflecting life cycle process of housing.

Quantitative presentation of various micro- and macro-level factors may be found in literature [14, 15]. Conceptual presentation of housing may also be found in literature $[2,3,4,5,16]$.

Under some programmes [17, 18, 19], conceptual as well as quantitative description (based on the former) of the present status of Lithuanian and advanced countries housing were made. This formalized presentation is given in Table 1 . Any $i$ factor of $j$ country is given $x_{1 i}$ code providing thorough quantitative (system of factors, measuring units, significances, values, as well as a minimizing or maximizing criterion) and conceptual (text. drawings. graphics, etc) information about the alternative being considered.

The magnitude of significance indicates how much in percentage one factor is more significant than the other in a multiple criteria evaluation of housing efficiency. As an example multiple, criteria evaluation of alternative loans from different Lithuanian financial institutions is given in Table 2 [11].

Basing oneself on quantitative description of the current state of housing in advanced countries, CEE and Lithuania it is possible to roughly evaluate the situation in Lithuanian housing in the transition period of its economic development. The conceptual description of the state of housing in advanced countries, CEE and Lithuania is also far from being exhaustive. There-

Table 1. A fragment of quantitative and conceptual description of the present state of housing in compared countries

\begin{tabular}{|c|c|c|c|c|c|c|c|c|c|}
\hline \multicolumn{10}{|c|}{ Quantitative information pertinent to compared countries } \\
\hline \multirow{2}{*}{$\begin{array}{l}\text { The factors } \\
\text { considered }\end{array}$} & \multirow{2}{*}{ * } & \multirow{2}{*}{$\begin{array}{l}\text { Signifi- } \\
\text { cance }\end{array}$} & \multirow{2}{*}{$\begin{array}{l}\text { Measuring } \\
\text { units }\end{array}$} & \multicolumn{6}{|c|}{ Numerical values of factors of the compared countries } \\
\hline & & & & $a_{1}$ & $a_{2}$ & $\ldots$ & $\mathbf{a}_{\perp}$ & $\ldots$ & $a_{n}$ \\
\hline $\begin{array}{l}\text { Quantitative } \\
\text { factors }\end{array}$ & $\begin{array}{l}\mathrm{z}_{1} \\
\mathrm{z}_{2} \\
\ldots \\
\mathrm{z}_{\mathrm{i}} \\
\ldots \\
\mathrm{z}_{1}\end{array}$ & $\begin{array}{l}q_{1} \\
q_{2} \\
\dddot{.} \\
q_{i} \\
\dddot{q} \\
q_{1}\end{array}$ & $\begin{array}{c}\mathbf{m}_{1} \\
\mathbf{m}_{2} \\
\ldots \\
\mathrm{m}_{\mathbf{i}} \\
\ldots \\
\mathrm{m}_{1}\end{array}$ & $\begin{array}{l}x_{11} \\
x_{21} \\
\ldots \ldots \\
x_{i 1} \\
\ldots . \\
x_{11}\end{array}$ & $\begin{array}{l}x_{1:} \\
x_{:-} \\
\ldots: \\
x_{1:} \\
\therefore: \\
x_{i 2}\end{array}$ & $\begin{array}{l}\ldots \\
\ldots \\
\ldots \\
\ldots \\
\ldots\end{array}$ & $\begin{array}{l}x_{11} \\
x_{-i} \\
\ddot{x}_{i} \\
\ddot{x}_{i}\end{array}$ & $\begin{array}{l}\ldots \\
\ldots . \\
\ldots \\
\ldots \\
\ldots \\
\end{array}$ & \begin{tabular}{c}
$\mathbf{x}_{1 \mathrm{n}}$ \\
$\mathbf{x}_{2 n}$ \\
\hdashline$\ldots$ \\
$\mathbf{x}_{\text {in }}$ \\
$\cdots \cdots$ \\
$\mathbf{x}_{\text {in }}$
\end{tabular} \\
\hline $\begin{array}{l}\text { Qualitative } \\
\text { factors }\end{array}$ & $\begin{array}{l}\mathbf{z}_{t+1} \\
\mathbf{z}_{1+2} \\
\dddot{z_{i}} \\
\ldots \\
\mathbf{z}_{\mathrm{m}}\end{array}$ & $\begin{array}{c}\mathbf{q}_{1+1} \\
\mathbf{q}_{1+2} \\
\ldots \\
\mathbf{q}_{i} \\
\ldots \\
\mathbf{q}_{m}\end{array}$ & $\begin{array}{c}\mathrm{m}_{\mathrm{itl}} \\
\mathrm{m}_{\mathrm{it2}} \\
\ldots \\
\mathrm{m}_{\mathrm{i}} \\
\ddot{m}_{\mathrm{m}}\end{array}$ & $\begin{array}{c}\mathbf{X}_{1+11} \\
\mathbf{X}_{t+31} \\
\ldots . \\
\mathbf{X}_{i 1} \\
\ldots \\
\mathbf{x}_{m L}\end{array}$ & $\begin{array}{c}x_{1+1:} \\
x_{1+:} \\
\ldots . \\
x_{i:} \\
\ldots \\
x_{m 2}\end{array}$ & $\begin{array}{c}\cdots \\
\cdots \\
\cdots \\
\cdots \\
\cdots\end{array}$ & $\begin{array}{c}x_{1+11} \\
x_{1+3 i} \\
\ldots \ldots \\
x_{i j} \\
\ldots \\
x_{m i}\end{array}$ & $\begin{array}{l}\cdots \\
\cdots \\
\cdots \\
\cdots \\
\cdots\end{array}$ & $\begin{array}{c}\mathbf{x}_{t+1 n} \\
\mathbf{x}_{t+2 n} \\
\cdots \cdots \\
\mathbf{x}_{i n} \\
\cdots \\
\mathbf{x}_{m n}\end{array}$ \\
\hline \multicolumn{10}{|c|}{ Conceptual information pertinent to compared countries } \\
\hline $\mathrm{C}_{\mathrm{f}}$ & $C_{2}$ & $\mathrm{C}_{4}$ & $\mathrm{C}_{\mathrm{m}}$ & $\mathbf{C}_{1}$ & C. & $\ldots$ & $C_{1}$ & $\ldots$ & $\mathrm{C}_{\mathrm{n}}$ \\
\hline
\end{tabular}

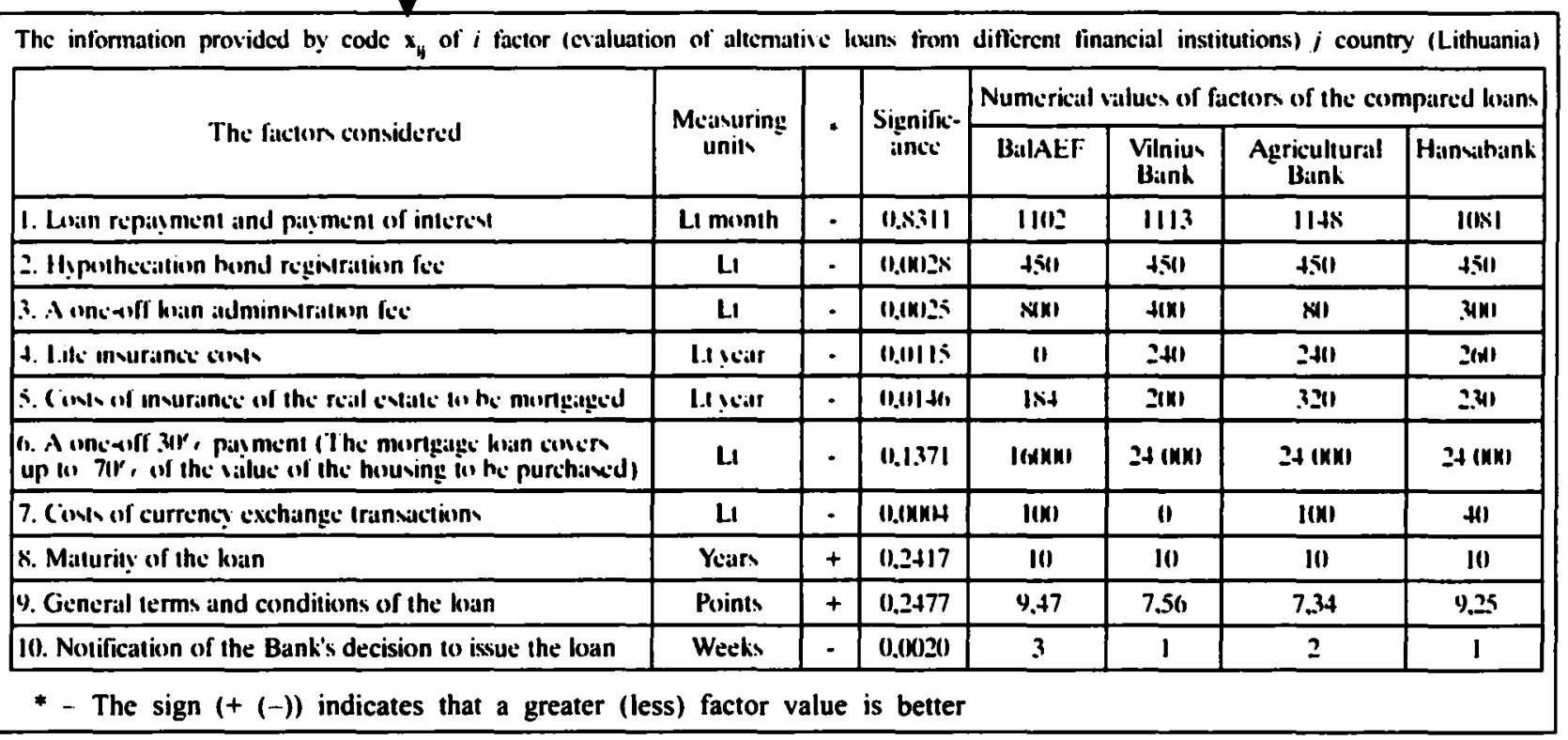


Table 2. Multiple criteria evaluation of altemative loans from different financial institutions

\begin{tabular}{|c|c|c|c|c|c|c|c|}
\hline \multirow{2}{*}{ The factors considered } & \multirow{2}{*}{$\begin{array}{c}\text { Measuring } \\
\text { units }\end{array}$} & \multirow{2}{*}{ * } & \multirow{2}{*}{$\begin{array}{c}\text { Signifi- } \\
\text { cance }\end{array}$} & \multicolumn{4}{|c|}{ Numerical values of factors of the compared loans } \\
\hline & & & & BalAEF & $\begin{array}{l}\text { Vilnius } \\
\text { Bank }\end{array}$ & $\begin{array}{c}\text { Agricultural } \\
\text { Bank }\end{array}$ & Hansabank \\
\hline 1. Loan repayment and payment of interest & Lu/month & - & 0,8311 & 1102 & 1113 & 1148 & 1081 \\
\hline 2. Hypothecation bond registration fec & $\mathbf{L t}$ & - & $0,(0028$ & 450 & 450 & 450 & 450 \\
\hline 3. A one-off loan administration fec & $\mathbf{L}$ & - & 0,0025 & 800 & $4(10)$ & 80 & 300 \\
\hline 4. Life insurance costs & Lt/vear & $\cdot$ & 0.0115 & 0 & 240 & 240 & 260 \\
\hline 5. Costs of insurance of the real estate to be morigaged & Luyear & $\cdot$ & 0,0146 & 184 & 200 & 320 & 230 \\
\hline $\begin{array}{l}\text { 6. A one-off } 30 \mathrm{r}_{i} \text { payment (The morngage loan covers up } \\
\text { io } 7 \mathbf{r}_{i} \text { of the value of the housing to be purchased) }\end{array}$ & $\mathbf{L} \mathbf{1}$ & $\cdot$ & 0,1371 & $16(000)$ & 240001 & 240000 & 24000 \\
\hline 7. Costs of currency exchange transactions & $\mathbf{L t}$ & - & 0,0004 & 100 & $\mathbf{0}$ & $\mathrm{I}(\mathrm{x})$ & 40 \\
\hline 8. Maturity of the loan & Years & + & 0.2417 & 10 & 10 & 10 & 10 \\
\hline 9. General terms and conditions of the loan & Points & + & 0,2477 & 9,47 & 7,56 & 7,34 & 9,25 \\
\hline 10. Notification of the Bank's decision lo issue the loan & Weeks & $\cdot$ & 0,0020 & 3 & 1 & 2 & 1 \\
\hline \multicolumn{4}{|c|}{ The sums of weighted normalized maximizing indices of the loans $S_{+}$} & 0,0856 & $0,076.3$ & 0.0752 & 0,0846 \\
\hline \multicolumn{4}{|c|}{ The sums of weighted normalized minimizing indices of the loans $S_{-1}$} & 0,1606 & 0,1627 & 0,1892 & 0,1658 \\
\hline \multicolumn{4}{|l|}{ Significance of the loans $Q$, } & 0,3152 & 0,3028 & 0,2700 & 0,3069 \\
\hline \multicolumn{4}{|l|}{ Priority of the loans } & 1 & 3 & 4 & 2 \\
\hline \multicolumn{4}{|l|}{ Utility degree of the loans $N$, } & $100 \%$ & $96,06 \%$ & $85,66 \%$ & $97,36 \%$ \\
\hline
\end{tabular}

fore, only a combination of two methods can yield a complete picture, demonstrating the actual situation in this field. A quantitative description should be supplemented by detailed conceptual explanation $[17,20]$. For more detailed analysis of the housing, with the aim of giving recommendations concerning the possibilities of raising its efficiency, fragmentary description of Lithuanian, advanced industrial countries and CEE housing were made in quantitative and conceptual forms.

The results of this quantitative and conceptual analysis may be widely used for identifying and solving the problems facing Lithuanian housing as far as ways and methods of raising its efficiency are concerned.

\section{Conclusions and suggestions}

Basing on the research performed it is possible to make the following conclusions and suggestions:

I. The performed examinations showed that it is possible lo diside methods and models of construction industry into two groups: quantitatice and qualitative ones. Therefore seeking for complex analysis of housing it is necessary to join the qualitative and quantitative evaluations. Only in such a case the complex housing analysis is possible.

2. An analytical complex analysis model of rational Lithuanian housing is developed. The performed examinations showed that the level of effectiveness of housing depends on a specific number of two level micro- and macro-level variable factors.

3. The performed examinations showed that while solving the problems of housing it is important to create the complex comparative systems of indices describing the housing. Two following systems of indices are suggested in the work:

- Complex system of indices allowing to evaluate the trends of housing policy and activities on a world-scale, and allowing to evaluate the housing in countries of different economic development. A system of indices allows to determine the problematic fields of housing and contradicting objectives of politics. The systen includes indices divided into five groups: indices describing economics as a whole complex: indices describing the housing construction. investments and financing: indices describing the countries of transitional peried: indices describing the colume. quantity and density of housing: indices describing the housing policy.

- The complex system of housing indices intended to evaluate housing of Lithuania. A system of such group of indices shows the potential problems of Lithuanian housing and assists in finding out methods and means to improve the current situa- 
tion. The system covers indices divided into six groups: 1) economic: 2) social: 3) qualitative, volume and density: 4) institutional structures: 5) legal bases: 6) political priorities.

4. The suggested methodology gives an opportunity to solve a lot of objectives of micro- and macrolevel analysis of housing.

5. It is seen out of the examinations performed that application of multiple criteria analysis methods allows. on the base of examination of alternative variants, to select the most efficient decisions, to perform the detailed analysis of decisions made, to adjust decisions.

\section{References}

1. P. Balchin. Housing policy. New York: Routledge, 1995. 312 p.

2. M. Ball, M. Harboe and M. Martens. Housing and social change in Europe and the USA. London: Routledge, 1990. 224 p.

3. R. C. Harvey, A. Ashworth. The construction industry of Great Britain. Oxford: Laxton's, 1997. 321 p.

4. J. Hegedus, S. K. Mayo, I. Tosics. Rytu ir Centrinès Europos šalił pereinamojo laikotarpio būsto sektorius / LR Statybos ir urbanistikos ministerija. Vilnius: Rekona, 1997. 46 p.

5. P. H. Hillebrandt. Analysis of the British construction industry. London: Macmillan Press, 1988. 338 p.

6. J. Hills. Unravelling housing finance: subsidies, benefits \& taxation. Oxford: Oxford University Press, 1991. 338 p.

7. J. Sillince. Housing policies in Eastern Europe and the Soviet Union. London: Routledge, 1990. 488 p.

8. A. von Hoffman. High ambitions: the past and future of American low-income housing policy // Housing Policy Debate. Vol. 7, No. 3, 1996, p. 423-446.

9. P. Malpass, A. Munie. Housing Policy and Practice. London: Macmillan Press. 1994. 360 p.

10. C. Zimmermann. Assisted home-ownership in France // Proceedings of the XXV IAHS World Housing Congress. Lisbon. Portugal 29 June 3 July 1998. Edited by V. Abrantes. Porto. 1998. 714 p.

11. A. Banaitis. Racionalaus bũsto statybos parinkimo modelis: Daktaro disertacija. Vilnius. 2000. $143 \mathrm{p}$.

12. 12. J. Flocod. Housing Indicators in Ausiralia: $A$ C $(01)$ sultative Methexd Netheriands Joumal of Housing and the Built Environment. Vill $x$. No 1. 194.3. p. 95 124.

13. I. K. Zaradakas. V: Jonaitis. A. Kakklauskias. A. Banaitis. Total Lifi Analysis. Modelling and Forecasting of Housing Industry in Lithuania / Procizedings of Regional Workshop "Housing and Environment" organized by United Nations Centre for Human Settlements (Habitat). Vienna Intemational Center, 2223 November 1999. Vienna: United Nations Centre for Human Settlements (Habitat). p. 360-372.

14. Transition report 1997. European Bank for Reconstruction and Development, London, 1997.
15. Transition report 1998. European Bank for Reconstruction and Development, London, 1998.

16. The Encyclopedia of Housing / ed. Willem van Vliet Thousand Oaks: SAGE Publications. 1998. 712 p.

17. A. Kaklauskas. Research output: Total life analysis. modelling and forecasting of construction in Lithuania. Ref.: Ace programme 1996. Project No: P96-6708-F. 1998.

18. Gyvenamosios statybos ir renovacijos tiksly susisteminimas: Ataskaita. LR Statybos ir urbanistikos ministerijos użsakymas / Temos vadovas A. Kaklauskas. Vilnius, 1997. 45 p.

19. Gyvenamuju namu statybos šakos ekonominio efektyvumo analizé ir rekomendacijos jai didinti: Ataskaita. LR Statybos ir urbanistikos ministerijos użsakymas / Temos vadovas E. K. Zavadskas. Vilnius. 1998. 81 p.

20. E. K. Zavadskas, L. Simanauskas. A. Kaklauskas. Sprendimu paramos sistemos statyboje. Vilnius: Technika, 1999. $235 \mathrm{p}$.

[teikta 20001206

\section{RACIONALAUS BÜSTO STATYBOS LIETUVOJE MODELIS}

\section{A. Banaitis}

\section{Santrauka}

Būsto statyba užima svarbią vietą ekonominèje, socialinèje ir technologinèje valstybès veikloje.

Būsto statybos problemos yra daugialypés ir nepakankamai kompleksiškai tyrinètos. Būsto statybos efektyvuma ir plètros tendencijas lemia daugelis mikro- ir makrolygmens aplinkos kintamuju veiksnių. Kai yra tokia dinamiška padėtis, kyla klausimas, kaip objektyviai prognozuoti būsto statybos plètrą. Viena iš galimybiu - būsto Lietuvoje modeliavimas siekiant ištirti efektyvią statybos aplinka.

Straipsnyje pateiktas racionalaus būsto statybos Lietuvoje teorinis kompleksinès analizès modelis.

Remiantis ivairiu pasaulyje taikomy būsto rodikliu sistemy analize, pasiūlytos kompleksinès būsto statybą apibūdinančios lyginamosios rodikliu sistemos. Rodikliai šiose sistemose traktuojami ne kaip paprasti statistiniai duomenys. bet kaip supaprastinti kompleksiniu objektu modeliai. Sudarytos rodikliu sistemos rodo ivairiu būsto statyboje dalyvaujančiu suinteresuoty grupiy interesus.

Straipsnyje pateikta būsto statybos aprašymo koncepcinc ir kickybine forma galimybiu analizè.

Straipsnyje siūloma tyrimu melodika leidżia spręsti juairius būsto statybos mikro- ir makrolyg̣mens analizès użdasinius. Siems ùddaviniams spręsti pritaikyti daugiakritcrincs analizis melodai.

Audrius BA.NAITIS. Dexiorr. Dept of Consiruction Technolon! and Management. Vilnius Ciediminas Technical Lniversity (V'GTL). Saulcetckio al. I1. LT-2(14) Vilnius. Lithuania. E-mail: audriusicu operamail.com

Graduated from Vilnius Technical University (since 1996 Vilnius Gediminas Technical University. VGTU). BSe (1994). MSc (1996). PhD (2000). Research interests: building economics and policy, management of construction. multiple criteria complex analysis of construction industry. 